\title{
Methods for Identifying Sources of Nitrogen Contamination of Ground Water in Valleys in Washoe County, Nevada
}

By Ralph L. Seiler

U.S. GEOLOGICAL SURVEY

Open-File Report 96-461

Prepared in cooperation with the WASHOE COUNTY DEPARTMENT OF COMPREHENSIVE PLANNING

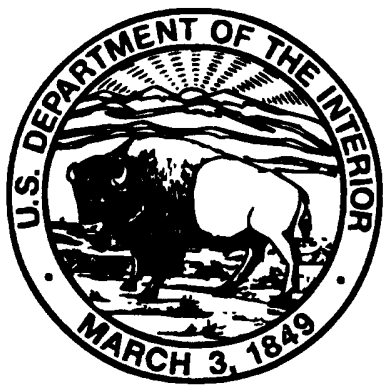

Carson City, Nevada 1996 


\title{
U.S. DEPARTMENT OF THE INTERIOR BRUCE BABBITT, Secretary
}

\author{
U.S. GEOLOGICAL SURVEY \\ Gordon P. Eaton, Director
}

Any use of trade, product, or firm names in this publication is for descriptive purposes only and does not imply endorsement by the U.S. Government

For additional information write to:

\section{District Chief}

U.S. Geological Survey 333 West Nye Lane, Room 203

Carson City, NV 89706-0866
Copies of this report can be purchased from:

U.S. Geological Survey

Branch of Information Services

Box 25286

Denver, CO 80225-0286 


\section{CONTENTS}

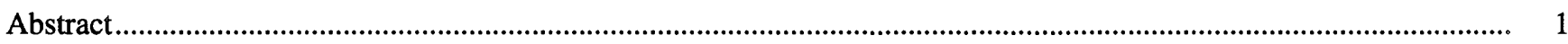

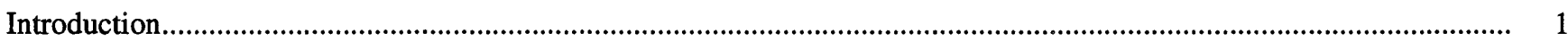

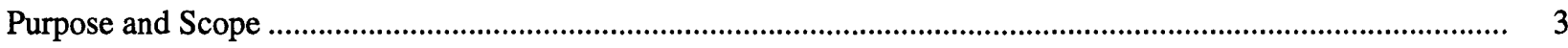

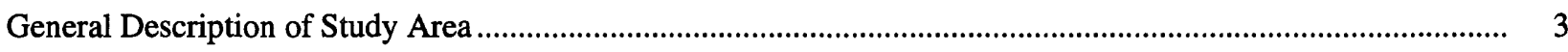

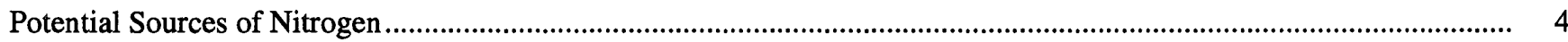

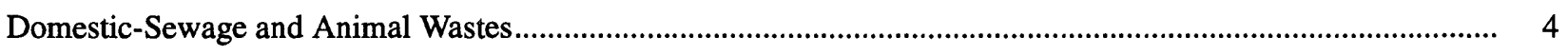

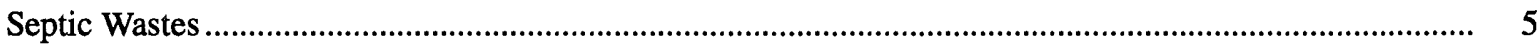

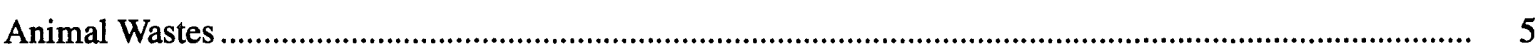

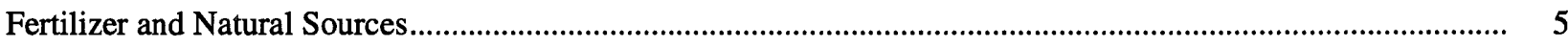

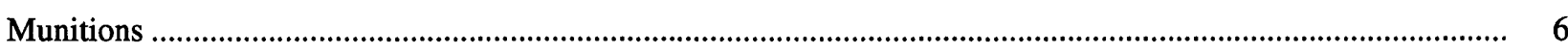

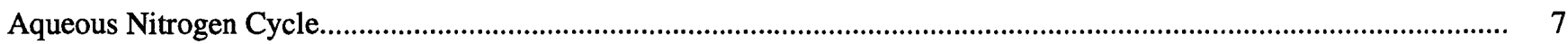

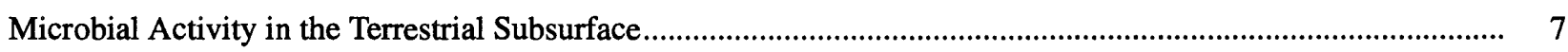

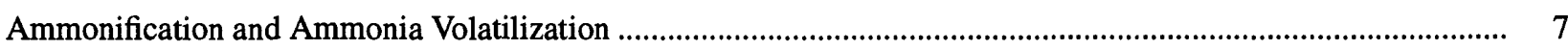

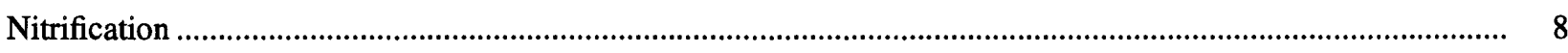

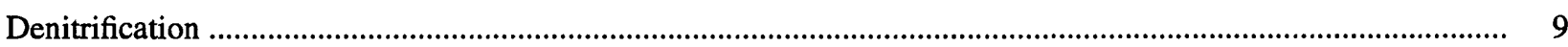

Dissimilatory Nitrate Reduction ................................................................................................................ 9

Nitrogen Fixation and Assimilation ........................................................................................................... 9

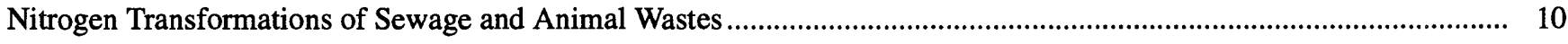

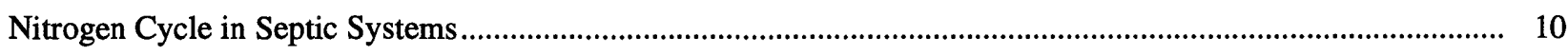

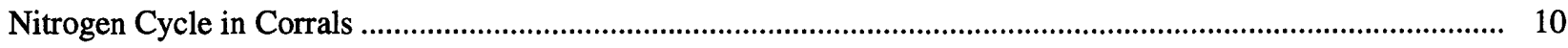

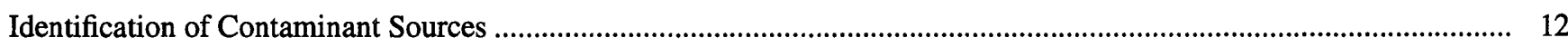

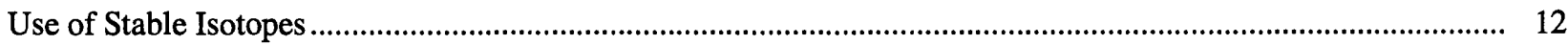

Use of Characteristic Chemical Components ....................................................................................... 13

Chemical Components of Domestic Sewage..................................................................................... 13

Chemical Components of Animal Wastes _................................................................................. 15

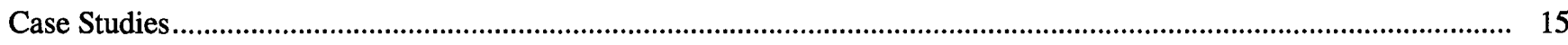

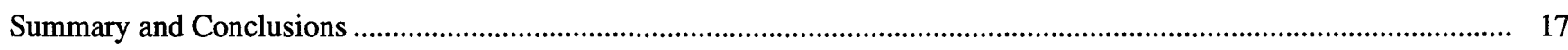

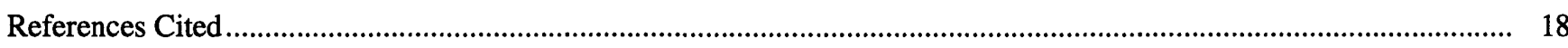

\section{FIGURES}

1. Map showing location of Lemmon Valley and Cold Spring Valley Hydrographic Areas, Nevada...................... 2

2. Schematic diagram of simplified nitrogen cycle, showing sources of nitrogen contamination of ground water.

3. Schematic diagram showing relation between design of on-site septic system and nitrogen cycle

\section{TABLES}

1. Summary of physiography of Lemmon and Cold Spring Valleys, Nevada ..................................................... 3

2. Nitrogen isotope ratios of common sources of nitrate found in water ............................................................. 12

3. Land use and nitrate characteristics of sand-plain aquifer in Minnesota .................................................... 16 


\section{CONVERSION FACTORS, VERTICAL DATUM, AND WATER-QUALITY UNITS}

\begin{tabular}{rcl}
\hline Multiply & By & To obtain \\
acre & 0.4047 & hectare \\
acre-foot & 1,233 & cubic meter \\
foot & 0.3048 & meter \\
gallon & 3,785 & liter \\
inch & 2.54 & centimeter \\
mile & 1.609 & kilometer \\
pound & 0.4536 & kilogram \\
pound per square foot & 4,882 & gram per square meter \\
square mile & 2.590 & square kilometer
\end{tabular}

Temperature: Degrees Celsius $\left({ }^{\circ} \mathrm{C}\right)$ may be converted to degrees Fahrenheit $\left({ }^{\circ} \mathrm{F}\right)$ by using the formula ${ }^{\circ} \mathrm{F}=\left[1.8\left({ }^{\circ} \mathrm{C}\right)\right]+32$. Degrees Fahrenheit $\left({ }^{\circ} \mathrm{F}\right)$ may be converted to degrees Celsius $\left({ }^{\circ} \mathrm{C}\right)$ by using the formula ${ }^{\circ} \mathrm{C}=5 / 9\left({ }^{\circ} \mathrm{F}-32\right)$.

Sea level: In this report, "sea level" refers to the National Geodetic Vertical Datum of 1929 (NGVD of 1929, formerly called Sea-Level Datum of 1929), which is derived from a general adjustment of the first-order leveling networks of the United States and Canada.

Abbreviated water-quality units used in this report:

$$
\begin{array}{lll}
\mu \mathrm{g} / \mathrm{g} \text { (microgram per gram) } & \mathrm{N}_{2} \text { (molecular nitrogen) } & \mathrm{NO}_{2} \text { (nitrite) } \\
\mathrm{mg} / \mathrm{L} \text { (milligram per liter) } & \mathrm{NH}_{3} \text { (ammonia) } & \mathrm{NO}_{3} \text { (nitrate) } \\
\mathrm{N} \text { (nitrogen) } & \mathrm{NH}_{4}^{+} \text {(ammonium ion) } & \text { organic- } \mathrm{N} \text { (organic nitrogen) }
\end{array}
$$

Method of reporting nitrogen concentrations: Nitrogen concentrations can be reported in different ways, and comparison of results between different investigations requires knowledge of how the nitrogen concentrations were reported. In older reports, nitrogen concentrations commonly were reported in terms of nitrate, nitrite, or ammonia. More recently, nitrogen concentrations have been reported in terms of an equivalent concentration of elemental nitrogen. For example, water containing $62 \mathrm{mg} / \mathrm{L}$ nitrate $\left(\mathrm{as} \mathrm{NO}_{3}\right)$ contains the same amount of nitrogen as $14 \mathrm{mg} / \mathrm{L}$ nitrate (as N).

Unless stated otherwise, nitrogen concentrations are reported as $\mathrm{N}$ in this report. Conversions from other ways of reporting are given in the table below.

\begin{tabular}{rll}
\hline Multiply & By & To obtain \\
\hline ammonia (as $\left.\mathrm{NH}_{3}\right)$ & 0.8235 & ammonia (as N) \\
ammonia (as equivalent $\left.\mathrm{NO}_{3}\right)$ & 0.2258 & ammonia (as N) \\
nitrite $\left(\mathrm{as}_{2}\right)$ & 0.3043 & nitrite (as N) \\
nitrite (as equivalent $\left.\mathrm{NO}_{3}\right)$ & 0.2258 & nitrite (as N) \\
nitrate $\left(\right.$ as $\left.\mathrm{NO}_{3}\right)$ & 0.2258 & nitrate (as $\mathrm{N})$ \\
\hline
\end{tabular}

Stable-isotope ratios are presented in terms of permil (parts per thousand). 


\title{
Methods for Identifying Sources of Nitrogen Contamination of Ground Water in Valleys in Washoe County, Nevada
}

\author{
By Ralph L. Seiler
}

\begin{abstract}
Nitrate concentrations exceeding drinkingwater standards have been reported in several wells in Lemmon and Golden Valleys in Washoe County, Nevada. Effective remediation requires identification of the actual sources of the contaminants. In Lemmon Valley, the most likely sources of the nitrate are septic tanks and animal corrals. A review of the technical literature indicates that a combination of several different analytes could provide a chemical fingerprint for ground water contaminated by septic-tank effluent. These analytes include stable isotopes of nitrogen, major ions, and consumer-generated organic chemicals (such as chlorofluorocarbons or caffeine). Ground water contaminated by waste from animal corrals may be characterized by stable isotopes and the presence of pharmaceuticals used in the medical treatment of large animals. A combination of chemical analyses will provide the best results in differentiating between sources of nitrogen contamination.
\end{abstract}

\section{INTRODUCTION}

Nitrogen contamination of ground water is a common problem in many valleys in Nevada. Knowledge of the sources of contamination is important because both treatment and prevention of contamination are very expensive. Several valleys in Nevada are contaminated with nitrate and residents oppose plans to connect households to wastewater-treatment plants because of the cost. Furthermore, many residents in contaminated areas do not believe that their on-site septic systems are the primary source of nitrate contamination.
The Maximum Contaminant Level (MCL) allowed for nitrate in public drinking water supplies in the United States is $10 \mathrm{mg} / \mathrm{L}$ (U.S. Environmental Protection Agency, 1986). The MCL for nitrate in public drinking water in Nevada is also $10 \mathrm{mg} / \mathrm{L}$ (Nevada Bureau of Health Protection Services, 1992). Nitrate concentrations exceeding $10 \mathrm{mg} / \mathrm{L}$ have been reported from several domestic wells in Lemmon and Golden Valleys (fig. 1) in Washoe County, Nev. (Widmer and McKay, 1994). Nitrate was the only nitrogen species reported; concentrations of other nitrogen species, such as ammonia and nitrite, also may be elevated. Cold Spring Valley (fig. 1), like Lemmon and Golden Valleys, is urbanizing rapidly and may have similar problems with nitrate contamination.

In some areas within Lemmon and Golden Valleys, septic-tank effluent is becoming the major component of recharge to the ground water. Localized ground-water withdrawals in residential parts of these valleys greatly exceed recharge, and water levels have declined as much as 60 feet during the last 20 years (Widmer and McKay, 1994). Nitrogen concentrations can be expected to increase because there is less uncontaminated water to dilute contaminants introduced by septic-tank effluent. Thus, ground water that now meets the standards may, in the future, exceed the MCL.

Widmer and McKay (1994) found that ground water with high nitrate concentrations is in areas served by onsite septic systems in almost all instances. However, in these same areas, percolating waste from large domestic animals (such as horses and cows) also may be making significant contributions to the nitrate-contamination problem. Effective remediation requires identification of the actual source(s) of the nitrogen contaminants; once the source is known, steps can be taken to minimize releases or exposure. 


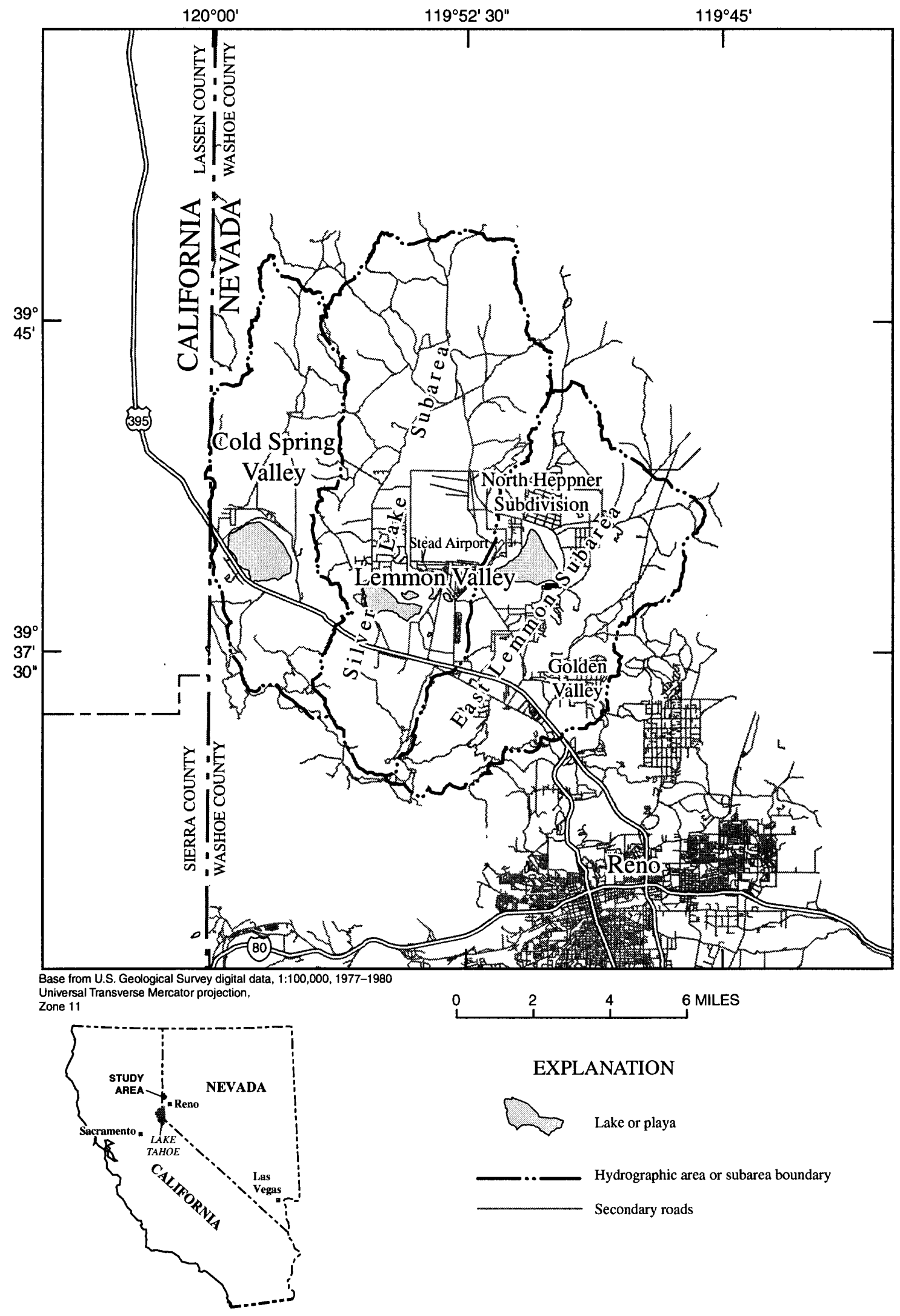

FIGURE 1.-Location of Lemmon Valley and Cold Spring Valley Hydrographic Areas, Nevada. 
This investigation was done as a cooperative effort between the U.S. Geological Survey and the Washoe County Department of Comprehensive Planning. Two objectives guided the investigation: (1) to develop methods of identifying sources of nitrogen contamination by establishing a suite of water-quality measurements and evaluating it in areas of known nitrate contamination in Golden and Lemmon Valleys, and (2) to identify sources and areal extent of nitrogen contamination in Lemmon and Cold Spring Valleys.

\section{Purpose and Scope}

The purpose of this report, which is the first product of the cooperative investigation, is twofold: to summarize literature concerning identification of sources of nitrogen contamination in ground water, and, on the basis of the literature, to propose a suite of water-quality measurements and analyses that may be able to identify sources of nitrogen contamination in Lemmon and Cold Spring Valleys. The conclusions in this report will guide subsequent data collection undertaken as part of the overall investigation.

The scope of the report is limited to those nitrogen sources that are important in Lemmon and Cold Spring Valleys.

\section{General Description of Study Area}

The study area includes the Lemmon Valley and Cold Spring Valley Hydrographic Areas ${ }^{1}$ (herein referred to as Lemmon and Cold Spring Valleys). Lemmon and Cold Spring Valleys are within 15 miles north-northwest of Reno and are in Washoe County, Nev., and Sierra County, Calif. These are topographically closed basins and have landforms typical of the Great Basin. Rush (1968) divided the Lemmon Valley Hydrographic Area into western and eastern parts. Harrill (1973) and subsequent authors have referred to the western part as the Silver Lake Subarea and the eastern part as the East Lemmon Subarea. Golden Valley and the Heppner Subdivision are in the East Lemmon Subarea. Physiographic data (Rush

\footnotetext{
${ }^{1}$ Formal hydrographic areas in Nevada were delineated systematically by the U.S. Geological Survey and Nevada Division of Water Resources in the late 1960's (Rush, 1968; Cardinalli and others, 1968) for scientific and administrative purposes. The official hydrographic-area names, numbers, and geographic boundaries continue to be used in Geological Survey scientific reports and Division of Water Resources administrative activities.
}

and Glancy, 1967) describing the valleys are summarized in table 1. Hydrographic areas and subareas are shown in figure 1 .

Land use in the area where elevated nitrate concentrations have been identified is predominantly residential. From data collected during the 1980 population census, the U.S. Commerce Department's Census Bureau prepared demographic data for Lemmon Valley as part of a neighborhood-statistics program (Washoe County Department of Comprehensive Planning, 1985). In 1980, 5,449 inhabitants occupied 1,679 households in Lemmon Valley, an average of 3.2 residents per household. In 1990, Lemmon Valley was not identified as a separate demographic area; rather it was treated as part of the larger North Valleys area by the Washoe County Department of Comprehensive Planning (J.A. Skow, oral commun., 1996). The North Valleys area, which includes Cold Spring, Lemmon, and Golden Valleys, had a population of 22,799 in 1990. About 2,250 residences are within the eastern part of Lemmon Valley (Widmer and McKay, 1994). Washoe County provides water service to about 1,100 and sewer service to 540 of those residences. The remainder of the residences are on domestic wells and onsite septic systems.

Two aquifers in Lemmon Valley were described by Harrill (1973). One is in fractured consolidated rock in the adjacent uplands and at depth beneath the valley fill, but the more productive and more developed aquifer is in the valley fill. Ground water flows from recharge areas in the mountains to discharge areas in playas in the center of the valley. A fault that separates the eastern and western parts of Lemmon Valley provides a barrier to ground-water flow in the valley fill.

In the East Lemmon Subarea, water levels in a residential area south of the unnamed lake/playa are shallow. In May 1996, water levels in four observation wells near Lemmon Valley School ranged from 1 to 10 feet below land surface (D.C. Dragan, Washoe County Department

TABLE 1.-Summary of physiography of Lemmon and Cold Spring Valleys in Nevada (from Rush and Glancy, 1967)

\begin{tabular}{lccc}
\hline Valley & $\begin{array}{c}\text { Area } \\
\text { (square } \\
\text { miles) }\end{array}$ & $\begin{array}{c}\text { Altitude } \\
\text { (feet) }\end{array}$ \\
\hline Lemmon Valley & 96 & 4,900 & $\begin{array}{c}\text { Adjoining } \\
\text { floor }\end{array}$ \\
Cold Spring Valley & 31 & 5,000 & $5,800-8,000$ \\
\hline
\end{tabular}


of Public Works, oral commun., 1996). Water levels in domestic wells are deeper north and east of the dry lake and range from 60 feet to more than 200 feet below land surface (Widmer and McKay, 1994). In Golden Valley, water levels range from about 40 feet to almost 300 feet below land surface (Widmer and McKay, 1994).

Estimated ground-water recharge from precipitation in the Lemmon Valley Hydrographic Area is 1,000 acrefeet per year in the Silver Lake Subarea and 500 acre-feet per year in the East Lemmon Subarea (Harrill, 1973). Van Hoozer (1994) modeled ground-water flow in the East Lemmon Subarea and estimated that recharge from precipitation is about 450 acre-feet per year. Recharge from septic systems is now providing a large component of the total ground-water recharge. Widmer and McKay (1994) estimated that effluent draining from leach lines was 200 gallons per day per household; thus, potential secondary recharge from septic effluent from the 1,710 households on septic systems in the East Lemmon Subarea is about 380 acre-feet per year. In recent years, the annual groundwater withdrawals, about 2,250 acre-feet per year, have become much greater than recharge in the East Lemmon Subarea (Widmer and McKay, 1994). Water levels have declined as much as 60 feet since the 1970's (Widmer and McKay, 1994). In a study emphasizing the effects of ground-water development in Lemmon Valley through 1971, Harrill (1973) presented chemical analyses (including nitrate) of water from many domestic wells in Golden Valley and in the Heppner Subdivision. At that time, he reported nitrate concentrations exceeding the primary MCL in only one well.

The median value for 230 ground-water temperatures presented by Widmer and McKay (1994) was $17.2^{\circ} \mathrm{C}\left(63^{\circ} \mathrm{F}\right)$. Ground-water temperature is important because it affects the rate of microbially mediated nitrogen transformations. At shallow depths, temperature in the subsurface follows seasonal variations in air temperature. Below about 30 to 60 feet, seasonal fluctuations in ground-water temperature are usually damped out and the temperature is relatively constant (Bouwer, 1978, p. 378).

The water resources of Cold Spring Valley were described by Van Denburgh (1981), who provided a hydrologic budget for the valley. Although all nitrate concentrations in ground-water samples for that study were below the MCL, he noted that nitrate concentrations in a public supply well increased from 0.5 to $2.2 \mathrm{mg} / \mathrm{L}$ between 1972 and 1979. He suggested that a shift of ground-water pumping for public supply to areas away from septic-tank/drain-field clusters would help postpone the inevitable need for a more permanent solution.

\section{POTENTIAL SOURCES OF NITROGEN}

Potential sources of the nitrogen in ground-water flow systems in Nevada include domestic sewage, animal wastes, fertilizers, natural sources, and munitions. Because the principal land use is suburban residential in Lemmon and Cold Spring Valleys, the primary sources of nitrogen contaminants are probably animal and domesticsewage wastes. In Lemmon Valley, high nitrate levels are almost always in unsewered areas, where wastewater is treated by on-site septic tanks (Widmer and McKay, 1994).

\section{Domestic-Sewage and Animal Wastes}

Domestic sewage in sparsely populated areas of the United States is disposed of primarily in on-site septic systems. In 1980, 20.9 million residences (about 24 percent of the total in the United States) disposed of about 4 million acre-feet of domestic sewage in on-site septic systems (Reneau and others, 1989). In rural areas of Nevada, central waste-treatment plants are not used because of their cost. Rather, domestic sewage is treated and disposed of in on-site septic systems. Inherent in this method is the discharge of effluent to the local ground water. To avoid contamination problems in an area, treated sewage effluent can be removed from a basin and discharged elsewhere if wastewater treatment is centralized. Unfortunately, removal is not possible with on-site septic systems, and even properly designed and constructed on-site septic systems frequently cause nitrate concentrations to exceed the MCL in the underlying ground water (Wilhelm and others, 1994).

Because of the large amounts of nitrogen excreted by large animals, confined animal operations have been identified as sources of nitrogen contamination in many areas of the United States. Grazing ruminants excrete 75 to 90 percent of the nitrogen they ingest, mostly as urea in urine (Ball and Ryden, 1984). Van Vuren (1949, p. 158) stated that the average cow, horse, and pig excretes 156 , 128 , and 150 pounds of nitrogen per year, respectively. Compared to domestic sewage, wastes produced by one horse contain twice as much nitrogen as that produced by a family of four during 1 year (Hantzsche and Finnemore, 1992). 


\section{Septic Wastes}

In presenting guidelines for the design of septic systems, the U.S. Environmental Protection Agency (1980) estimated that influent of liquid wastes to septic systems averages about 45 gallons per day per person. This value is somewhat less than that estimated for Lemmon Valley. Using data for Lemmon Valley (3.2 people per household and 200 gallons per day per household), about 62 gallons of liquid waste per day per person is discharged to septic systems.

The total-nitrogen concentration in septic-tank influent wastewater averages $50 \mathrm{mg} / \mathrm{L}$, of which $12 \mathrm{mg} / \mathrm{L}$ is in the ammonium $\left(\mathrm{NH}_{4}^{+}\right.$) form (Canter and Knox, 1986, p. 47-48). The treatment process in the septic tank removes some of the nitrogen in the waste through ammonia volatilization, denitrification, sorption on sediments, and retention in organic matter. Winneberger (1984) presented chemical analyses of septic-tank sludge and concluded that most of the nitrogen removed from the septicsystem influent was organic nitrogen. Organic nitrogen settles in scums and sludges that remain in the septic tank until it is cleaned and pumped out.

Total-nitrogen concentrations in septic-tank effluent range from $25 \mathrm{mg} / \mathrm{L}$ to as much as $100 \mathrm{mg} / \mathrm{L}$, and the average is in the range 35 to $45 \mathrm{mg} / \mathrm{L}$ (U.S. Environmental Protection Agency, 1980), of which about 75 percent is ammonium and 25 percent is organic (Canter and Knox, 1986, p. 76). Alhajjar and others (1989) analyzed effluent from 17 septic systems in Wisconsin approximately on a monthly basis for 2 years. For the 356 samples, total-nitrogen concentrations ranged from 10 to 141 $\mathrm{mg} / \mathrm{L}$ and averaged $73 \mathrm{mg} / \mathrm{L}$. Walker, Bouma, Keeney, and Magdoff (1973) reported the average nitrogen concentration in septic-tank effluent from four residences in Wisconsin as about 75 to $90 \mathrm{mg} / \mathrm{L}$. On the basis of the range of average values for total-nitrogen concentrations presented above ( 35 to $90 \mathrm{mg} / \mathrm{L}$ ) and 200 gallons per day (757 liters per day) as the average household discharge of septic-tank effluent in the study area (Widmer and McKay, 1994), the average household discharge of nitrogen to ground water would be 9.7 to 24.9 kilograms ( 21 to 55 pounds) per year.

In the East Lemmon Subarea, about 1,700 households use on-site septic systems (Widmer and McKay, 1994). According to the above estimates of average annual nitrogen contributions per household, septic-tank effluent in the East Lemmon Subarea could contribute from about 16,500 to 42,000 kilograms (18 to 46 tons) of nitrogen to the ground water annually. Which end of this wide range is nearer actual values for Lemmon Valley is difficult to assess from existing data. Studies reporting nitrogen concentrations in septic-tank effluent in Nevada were not identified. Many of the septic-system investigations were done in parts of the United States where water use and household activities may differ greatly from those typical of Nevada. For example, some studies of nitrogen concentrations in septic-tank effluent have excluded garbage-disposal contributions to the wastewater (Canter and Knox, 1986).

\section{Animal Wastes}

Many residents of Lemmon Valley maintain horses for recreation, and many of the residents of subdivisions in the East Lemmon Valley Subarea maintain more than five large animals (Widmer and McKay, 1994). Because animal wastes may accumulate on the ground in the corrals and contain very high levels of nitrogen, animal wastes could contribute significant amounts of nitrogen to ground water. However, their actual importance as sources of nitrogen in ground water is unknown. Many investigations of nitrogen contamination from high-density confined feedlot operations in humid environments have been made. Although corrals in Lemmon Valley are low-density operations in an arid environment, processes involved in nitrogen contamination below feedlots probably can be applied in a general way to corrals.

Animal wastes may lose much of the nitrogen by ammonia volatilization, particularly in corrals that are not subject to water application; water can transport the nitrogen to the subsurface before substantial volatilization has occurred. The amount of nitrate from animal wastes that percolates to the ground water depends on the amount of nitrate formed from the wastes, the infiltration rate, the frequency of manure removal, the animal density, the soil texture, and the ambient temperature (National Academy of Sciences, 1978). Stewart and others (1967) showed that there are large differences in the amount of nitrate found in soils under feedlots; some contain large amounts and some are nearly free of nitrate.

\section{Fertilizer and Natural Sources}

Fertilizers, naturally occurring organic material in the soils, and precipitation are probably minor sources of the nitrogen in the ground water in the Lemmon and Cold Spring Valleys. Nitrogen fertilizers are obvious potential sources, and nitrate contamination of ground water has been attributed to them in other areas. The amount of nitrogen contributed to the ground water by fertilizer 
depends on several factors, including the type and amount of fertilizer applied, the acidity $(\mathrm{pH})$ of the soil, the air temperature at the time of application, and the amount of water applied after fertilization. Hantzsche and Finnemore (1992) estimate that the nitrogen load to ground water from fertilization of lawns in residential subdivisions and rural communities is in the range 0.5 to 1.5 kilograms (1.1 to 3.3 pounds) per developed acre per year.

Decay of natural organic material in the ground can contribute substantial amounts of nitrogen to ground water. For example, in the late 1960's in west-central Texas several cattle died from drinking ground water containing high concentrations of nitrate; the source of the nitrate was determined to be naturally occurring organic material in the soil (Kreitler and Jones, 1975). The average nitrate concentration (as $\mathrm{NO}_{3}$ ) for 230 wells was 250 $\mathrm{mg} / \mathrm{L}$, and the highest concentration exceeded 3,000 $\mathrm{mg} / \mathrm{L}$. Native vegetation, which included a nitrogen-fixing plant, was destroyed by plowing of the soil for dryland farming. This increased oxygen delivery to the soil, and the nitrate causing the contamination was formed by oxidation of the naturally occurring organic material in the soil.

Patt and Hess (1976) identified naturally occurring, buried plant material as a possible source of nitrate contamination near Las Vegas, Nev. They conducted a massbalance analysis to identify the sources of nitrate contaminating domestic wells. According to their conclusions, a deposit of organic matter the equivalent of 1 meter ( $3 \mathrm{feet}$ ) thick, 1 kilometer (0.6 mile) wide, and 2 kilometers ( 1.2 mile) long would be required to supply the amount of nitrate observed in the ground water. Although this amount of organic matter could supply the nitrate, Patt and Hess (1976) had no direct evidence that such a volume of organic matter actually existed and was the source of nitrogen in their study area.

Precipitation contains nitrogen and thus is a potential source of the nitrogen in ground water in the area. Typically concentrations of nitrate in rainfall range from 0.1 to $0.7 \mathrm{mg} / \mathrm{L}$ (National Academy of Sciences, 1978, p. 126). The National Atmospheric Deposition Program (NRSP-3)/National Trends Network (NADP/NTN) of Colorado State University measures nitrogen concentrations in precipitation in Smith Valley, which is about 60 miles southeast of Lemmon Valley. For the period 19861993, the mean annual average-precipitation-weighted concentration of ammonia was $0.30 \mathrm{mg} / \mathrm{L}$ and of nitrate was $0.76 \mathrm{mg} / \mathrm{L}$ (Colorado State University at Fort Collins, NADP/NTN Coordination Office, Natural Resource Ecology Laboratory, written commun., 1994).
The amount of nitrogen contributed by precipitation can be estimated by using the long-term mean annual precipitation at Stead Airport (in Lemmon Valley), which is 8.4 inches (D.L. Berger, written commun., 1996). By using the sum of ammonia and nitrate concentrations for Smith Valley $(1.06 \mathrm{mg} / \mathrm{L})$ as the total-nitrogen concentration in precipitation in Lemmon Valley, precipitation is estimated to contribute about 0.91 kilogram ( 2.0 pounds) of nitrogen per acre per year.

An unknown amount of this nitrogen reaching the land surface would be volatilized, used by plants, or denitrified in saturated soils that are rich in organic matter; thus, the amount of nitrogen reaching the ground water is probably much less than $0.91 \mathrm{~kg}$ per acre. In their study area in Wisconsin, Walker, Bouma, Keeney, and Olcott (1973) estimated that about 3.25 kilograms (7.2 pounds) of nitrate per acre was contributed to the land surface by precipitation and that 12.5 to 25 percent of that could reach the ground water. Applying these proportions to the above estimates of nitrogen loading to Lemmon Valley, the total nitrogen contributed to ground water by precipitation in the study area could be about 0.11 to 0.22 kilogram ( 0.24 to 0.5 pound) per acre per year.

In Lemmon Valley, natural sources of nitrogen are probably minor compared to septic-tank effluent. Walker, Bouma, Keeney, and Olcott (1973) estimated that natural mineralization of soil organic material and precipitation together produce about 4 to 5 kilograms (8.8 to 11 pounds) of nitrogen per acre per year that may reach the ground water. These values probably are higher than contributions from natural sources in Lemmon Valley for several reasons. The most-common native plants in Lemmon Valley are not nitrogen fixing; the precipitation and thus plant density are much less in desert valleys in Nevada than in the areas in the Eastern and Midwestern United States where Walker, Bouma, Keeney, and Olcott (1973) did their studies. Furthermore, they used a higher value for nitrogen contribution from precipitation than that calculated for Lemmon Valley ( 0.9 kilograms or 2 pounds per acre). Even if their value is applicable to Lemmon Valley, the annual nitrogen contribution to the ground water by the effluent from a septic tank serving a family of four on a 1-acre lot in the study area potentially is two to six times more than that from natural sources.

\section{Munitions}

Dynamite and other explosives contain nitrogen, and breakdown of the explosives can contribute nitrogen to the ground water. Nitrogen contamination of the ground water has been found at facilities in Nevada where 
munitions have been processed (Van Denburgh and others, 1993). Until 1966 Stead Air Force Base, in the center of Lemmon Valley, operated primarily as a survival-training facility; no reports of nitrogen contamination resulting from those operations have been identified.

\section{AQUEOUS NITROGEN CYCLE}

Nitrogen is present in waters in both inorganic and organic forms. Dissolved inorganic forms are ammonia (both $\mathrm{NH}_{3}$ and $\mathrm{NH}_{4}^{+}$), nitrite, nitrate, and molecular nitrogen. Organic forms can be dissolved or particulate. Except for anthropogenic chemicals such as pesticides, organic nitrogen in water is derived from chemicals metabolized by living organisms.

Most steps in the nitrogen cycle are mediated by microbes, which either use the reactants as source materials for biosynthesis or use the reaction itself for deriving energy. Some of the reactions are shown in figure 2. Molecular nitrogen occurs in the atmosphere in vast amounts, but few organisms can utilize it because of the strength of the nitrogen-nitrogen triple bond. Living organisms rapidly convert other nitrogen species from one form to another.

\section{Microbial Activity in the Terrestrial Subsurface}

Ghiorse and Wilson (1988) reviewed the literature about the presence and activities of microbes in the terrestrial subsurface. Substantial numbers of micro-organisms are present in subsurface sediments and occur in numbers great enough to exert a marked effect on ground-water chemistry (Balkwill, 1989). Growth rates of these organisms are probably very low under normal circumstances because of limited nutrients, organic carbon in particular (Ghiorse and Wilson, 1988).

Because most of the steps in the nitrogen cycle are mediated by microbes, environmental factors such as temperature, $\mathrm{pH}$, and dissolved-oxygen concentrations at and below the land surface have a strong influence on the speed of conversion from one form of nitrogen to another. Temperature is one of the most important environmental factors because of its effects on biological activity in general. For most plant species, the rate of respiration doubles with an increase in temperature of $10^{\circ} \mathrm{C}$ within the range 5 to $25^{\circ} \mathrm{C}$ (Salisbury and Ross, 1969). Biological activity typically is very slow near freezing, although it does occur.
Which microbial populations are active in the subsurface (and thus which nitrogen transformations occur) depends on the dissolved-oxygen concentration. The most-common nitrifying bacteria, Nitrosomonas and Nitrobacter, which convert ammonia to nitrate, are strict aerobes and the conversion of ammonia to nitrate does not occur in anaerobic environments. Similarly, denitrifying bacteria require anaerobic conditions in the microenvironment for the conversion of nitrate to nitrogen gas. In sewage sludge, denitrification can occur even under high oxygen concentrations, probably because of the existence of anaerobic regions in the sludge (Okada and others, 1978).

\section{Ammonification and Ammonia Volatilization}

Although many organic compounds contain nitrogen, the principal nitrogen-containing organic compounds in human and animal wastes are urea and proteins, both of which contain nitrogen as amine groups $\left(-\mathrm{NH}_{2}\right)$. Urea has the chemical structure

$$
\mathrm{H}_{2} \mathrm{~N}-\mathrm{CO}-\mathrm{NH}_{2} \text {. }
$$

Proteins are made of amino acids, which have the general structure

\section{$\mathrm{H}_{2} \mathrm{~N}-\mathrm{CH} R-\mathrm{COOH}$,}

where the symbol $R$ is used to refer a side chain. For example, $R$ represents a methyl group $\left(-\mathrm{CH}_{3}\right)$ in the amino acid alanine. Almost all the nitrogen found in untreated domestic sewage is associated with proteins and urea (Tchobanoglous and Burton, 1991). Most of the nitrogen from urea is in the form of ammonia; because urea decomposes so rapidly, it is seldom found in other than very fresh wastewater.

The first step in the microbial decomposition of organic nitrogen is called ammonification. This process, also called mineralization, releases ammonia, which may be assimilated into microbial tissue or may be excreted to the environment. In agricultural soils, ammonification is principally an aerobic process because the rate of mineralization mediated by aerobic bacteria is much greater than that by anaerobic bacteria (Vinten and Smith, 1993). Plants probably metabolize urea by hydrolyzing it into one molecule of carbon dioxide and two molecules of ammonia (Salisbury and Ross, 1969). 


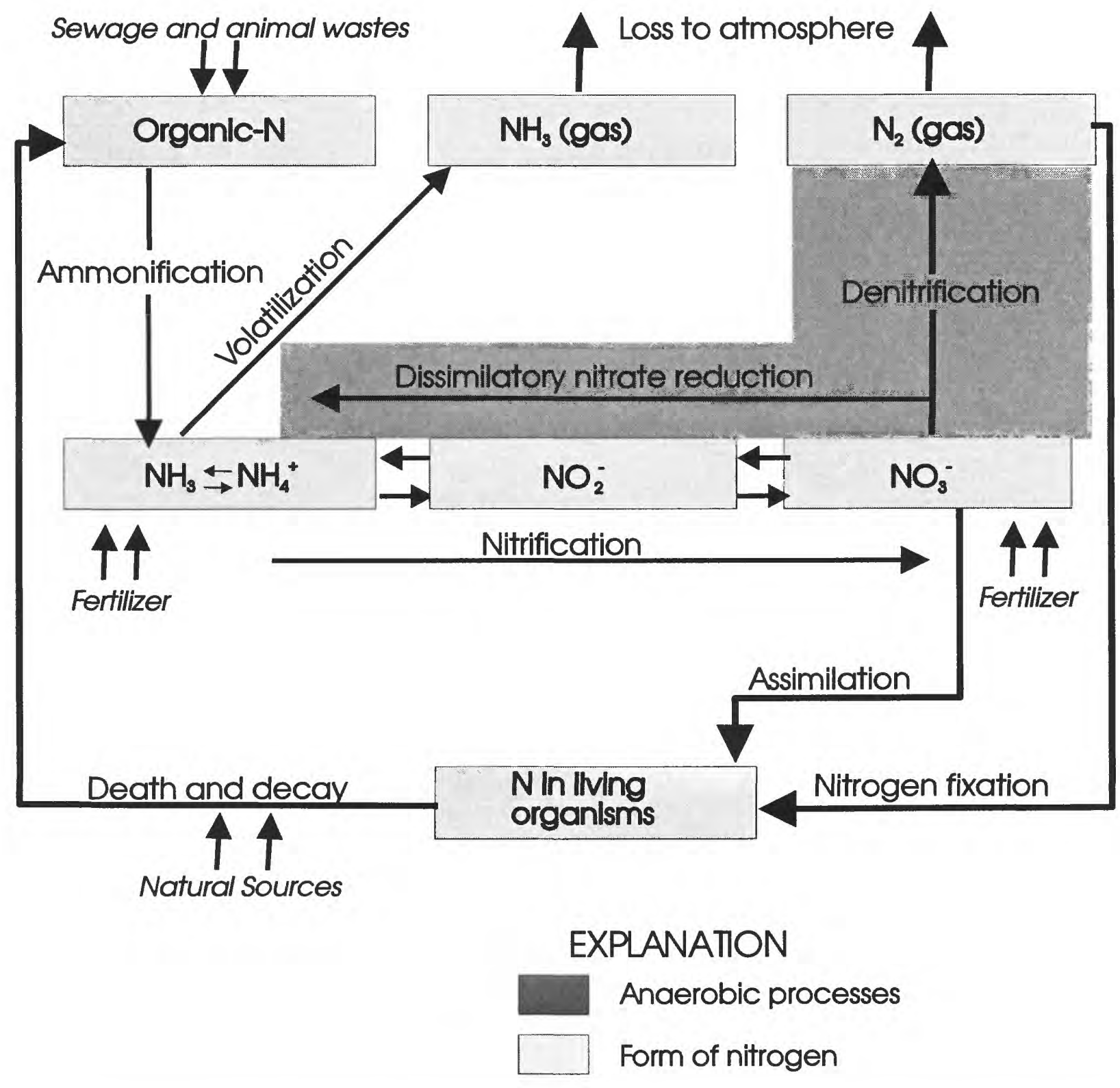

FIGURE 2.-Simplified nitrogen cycle, showing sources of nitrogen contamination of ground water.

Ammonia volatilization is the release of ammonia from water to the atmosphere as a gas. This process strongly depends on the temperature and $\mathrm{pH}$ of the water. This is because ammonia can exist in the un-ionized form as ammonia or in the ionized form as the ammonium ion, and the un-ionized form is more volatile because it is an electrically neutral gas. At high temperatures and at $\mathrm{pH}$ values greater than 8 , much more of the ammonia is in the un-ionized form and volatilization is more likely.

\section{Nitrification}

Nitrification is the conversion of ammonium to nitrate. It is a two-stage oxidation process:

$$
\mathrm{NH}_{4}^{+} \rightarrow \mathrm{NO}_{2}^{-} \rightarrow \mathrm{NO}_{3}^{-} \text {. }
$$

The first step, the oxidation of ammonium to nitrite, is mediated almost exclusively by bacteria in the genus Nitrosomonas, and the second step, the oxidation of nitrite 
to nitrate, is mediated principally by bacteria in the genus Nitrobacter (Lehninger, 1970). Because the first step in nitrification is normally much slower than the second step, high concentrations of the intermediate nitrite species rarely persist in natural systems (Heathwaite, 1993).

These bacteria are extremely abundant and active. They obtain their carbon for growth from $\mathrm{CO}_{2}$ and nearly all their energy from the oxidation of ammonium and nitrite. The nitrification process demands oxygen because the bacteria are strict aerobes and require dissolved-oxygen concentrations of about $2 \mathrm{mg} / \mathrm{L}$ or greater to function efficiently (Heathwaite, 1993).

Wild and others (1971) discussed environmental factors affecting rates of nitrification in wastewater treatment. Nitrification rates strongly depend on ambient temperature and on $\mathrm{pH}$. The optimum $\mathrm{pH}$ for nitrification is in the range 8.4 to 8.6 , and, at $\mathrm{pH} 7.0$, the rate of nitrification is less than half the rate at $\mathrm{pH} 8.4$ (Wild and others, 1971). The rate increases with temperature within the range 5 to $30^{\circ} \mathrm{C}$; the rate at $15^{\circ} \mathrm{C}$ is less than half the rate at $30^{\circ} \mathrm{C}$ (Wild and others, 1971).

\section{Denitrification}

Denitrification is the process that completes the nitrogen cycle and returns nitrogen to the atmosphere as a gas. Denitrification occurs in a number of steps:

$$
\mathrm{NO}_{3}{ }^{-} \rightarrow \mathrm{NO}_{2}{ }^{-} \rightarrow \mathrm{N}_{2} \mathrm{O} \rightarrow \mathrm{N}_{2} \text {. }
$$

Incomplete denitrification releases nitrous oxide $\left(\mathrm{N}_{2} \mathrm{O}\right)$ to the atmosphere. Denitrification is mediated by anaerobic micro-organisms, a different group catalyzing each step.

Most denitrifying bacteria are facultative aerobes; that is, the bacteria can grow in the presence of oxygen, but the bacteria's immediate microenvironment must be anaerobic if denitrification is to occur (Paerl, 1993). Denitrification can occur in soils with oxygen concentrations of 4 to 17 percent (Vinten and Smith, 1993, p. 46) because local, small-scale anaerobic zones can develop in aerobic environments. However, the lower the measurable oxygen concentration, the larger the anaerobic zones will be and the faster denitrification will occur. Rainfall, irrigation, and other events that wet soils increase the rate of denitrification because the rate of oxygen diffusion through a water-filled pore is only one ten-thousandth that through an open pore (Vinten and Smith, 1993, p. 46).
The optimum temperatures for denitrification in soil are $25^{\circ} \mathrm{C}$ and above, and minimum temperatures for denitrification are in the range 2.7 to $10^{\circ} \mathrm{C}$ (Vinten and Smith, 1993). The effect of $\mathrm{pH}$ on denitrification is unclear because changes in $\mathrm{pH}$ can change the availability of organic carbon (Vinten and Smith, 1993), which is needed for denitrification to occur.

\section{Dissimilatory Nitrate Reduction}

Under anaerobic conditions where organic content is high, nitrate may be reduced by ammonifying bacteria to ammonia via nitrite (Howard-Williams and Downes, 1993). During dissimilatory nitrate reduction, unlike during denitrification, nitrogen is retained in the system and is not lost to the atmosphere. Furthermore, under the anaerobic conditions during which dissimilatory nitrate reduction occurs, the ammonia produced may become immobile by being retained on exchange sites in the sediments. Dissimilatory nitrate reduction can occur along with denitrification and may be a common feature in wetland habitats that have high organic content (HowardWilliams and Downes, 1993)

\section{Nitrogen Fixation and Assimilation}

Nitrogen fixation is the process by which blue-green algae and certain bacteria use molecular nitrogen from the atmosphere as a nitrogen source. Several thousand species of higher plants, almost all of them members of the pea family (Leguminosae), have evolved a symbiotic relation with nitrogen-fixing bacteria and are able to fix nitrogen in nodules on their roots (Salisbury and Ross, 1969). Alfalfa, which is a legume and can fix atmospheric nitrogen, is a common crop plant in northern Nevada.

Assimilation is the absorption of inorganic nitrogen by living organisms and its incorporation into living tissue. Most plants can absorb both ammonium and nitrate ions; however, nitrate is usually the preferred source (Salisbury and Ross, 1969). Nitrate absorbed by the roots of higher plants is reduced rapidly to ammonia, usually within the root, and assimilated rapidly into organic compounds. 


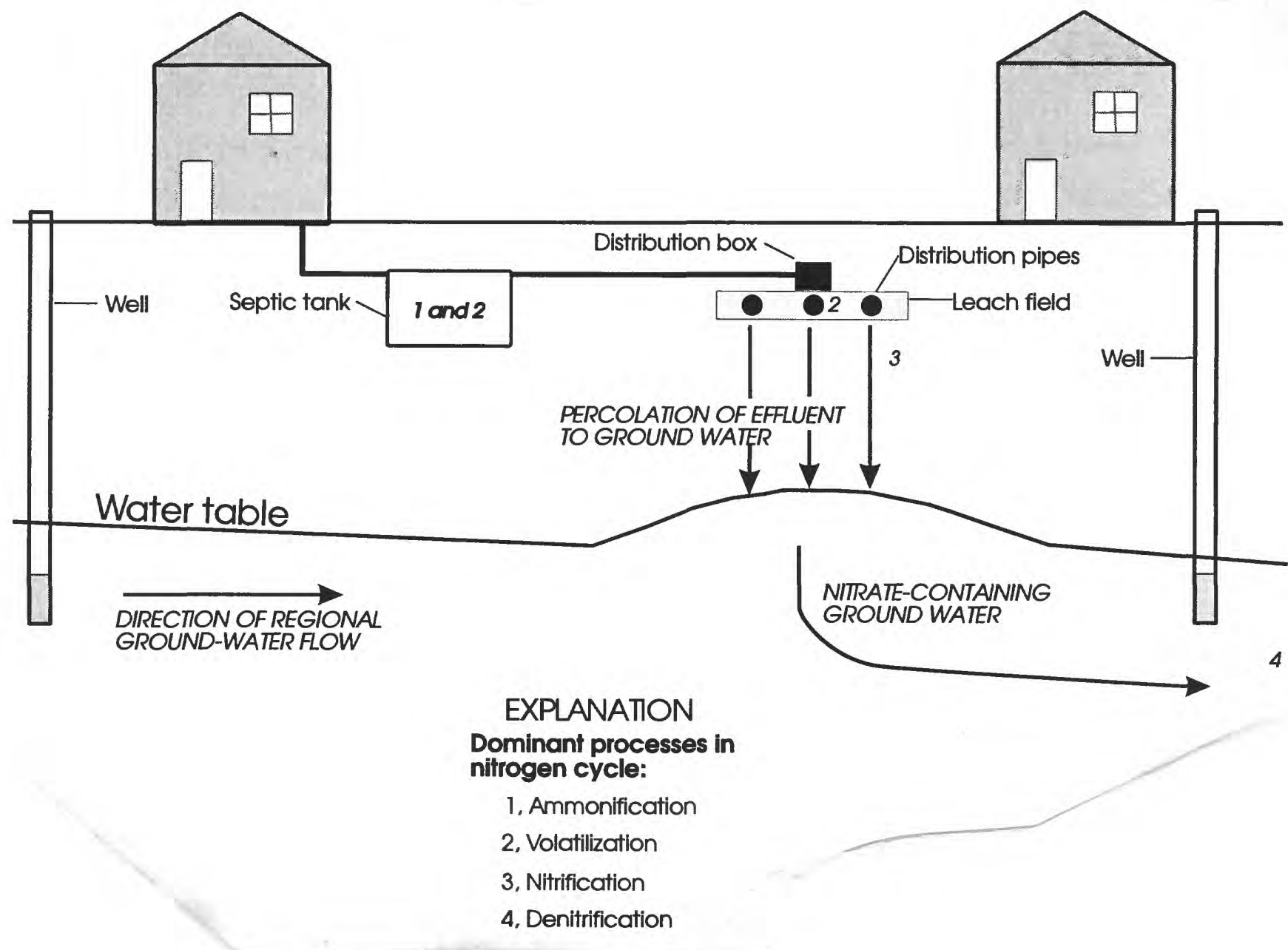

FIGURE 3.-Relation between design of on-site septic system and nitrogen cycle.

Urea in cow urine reacts rapidly with the enzyme urease in the feces, resulting in a high $\mathrm{pH}$ and the formation of ammonia (Lauer and others, 1976). Losses of ammonia from the waste can be substantial because the increase in the $\mathrm{pH}$ results in the formation of un-ionized ammonia, which is volatile.

Weather conditions affect how much nitrogen in animal wastes actually infiltrates the subsurface. Lauer and others (1976) reported that snow covering manure precluded ammonia loss by volatilization and that about 66 percent of the ammonia in the manure moved into the soil profile. Stewart (1970) simulated wetting and drying conditions found in feedlots and demonstrated that when cattle urine was applied to dry soil, about 90 percent of the nitrogen was lost by ammonia volatilization; when urine was applied to initially wet soils, less than 25 percent of the ammonia was lost to volatilization and about 65 percent was converted to nitrate.
Air temperature affects the amount of nitrogen that is lost through ammonia volatilization and thus the amount that remains in the manure and is available for infiltration into the subsurface. Drying of manure in response to evaporative conditions drives the process of ammonia volatilization (Lauer and others, 1976) by increasing ammonia concentrations in the manure and by increasing the rate at which ionized ammonia disassociates to the more-volatile, un-ionized form that is lost to the atmosphere. Vinten and Smith (1993, p. 51), citing data from La Lande Cremer (1986), showed that in grasslands when the air temperature is $30^{\circ} \mathrm{C}$, almost all the nitrogen in liquid manure applied to the land surface is lost to the atmosphere but when the air temperature is $10^{\circ} \mathrm{C}$, only about 30 percent is lost.

La Lande Cremer (1986) found that at $30^{\circ} \mathrm{C}$ even very shallow disposal of animal waste significantly limits 


\section{NITROGEN TRANSFORMATIONS OF SEWAGE AND ANIMAL WASTES}

Sewage and animal wastes have different characteristics and are disposed of and treated in different ways. Because of these differences, it may be possible to distinguish between the two as sources of nitrogen contamination. The following two sections describe how the wastes differ and how the method of treatment affects nitrogen transformations of animal and domestic waste.

\section{Nitrogen Cycle in Septic Systems}

Wilhelm and others (1994) provided a detailed description of the processes that occur in on-site septic systems and Reneau and others (1989) reviewed literature on the fate and transport of contaminants from on-site septic systems. Figure 3 shows the design of an on-site septic system and where processes in the nitrogen cycle occur. In the septic tank itself, dissolved-oxygen concentrations are very low and the concentration of organic matter is high. Anaerobic digestion occurs in the septic tank and most nitrogen is released from organic molecules as the ammonium ion. Waste is not exposed directly to the atmosphere, temperature is low, moisture is high, and air movement is inhibited; these conditions minimize ammonia volatilization in some septic tanks and filter fields (Wells and Krothe, 1989; Aravena and others, 1993).

Approximately 10 to 30 percent of the total nitrogen is incorporated into the sludge and remains in the septic tank. Septic-tank effluent moves into aerobic, unsaturated sediments in the drain field. Nitrogen in the effluent is primarily in the form of ammonia. Brown and others (1984) studied the nitrogen content of effluent from a septic tank serving nine families. Of the total-nitrogen concentration, which averaged $29.8 \mathrm{mg} / \mathrm{L}$, ammonia constituted 77.7 percent, organic nitrogen 21.5 percent, and nitrate 0.8 percent. Walker, Bouma, Keeney, and Magdoff (1973) presented chemical analyses of septic effluent from five systems. Ammonia averaged 80 percent and organic nitrogen 20 percent; virtually no nitrate was detected.

Beneath properly functioning septic fields, almost all the organic matter in the septic-tank effluent is oxidized and nitrification oxidizes ammonia to nitrate. The conversion of ammonia to nitrate can occur rapidly (within a few hours) and occurs close to the septic-field distribution pipes (Wilhelm and others, 1994). Walker, Bouma, Keeney, and Magdoff (1973) reported that ammonia concentrations in soil decreased from $62 \mu \mathrm{g} / \mathrm{g}$ at 1 centimeter ( 0.4 inch) below a septic field to $4 \mu \mathrm{g} / \mathrm{g}$ at 6 to 7 centimeters ( 2.4 to 2.8 inches) below.

Because nitrification requires an aerobic environment, conversion of ammonia to nitrate may not be complete in poorly aerated septic fields and ammonia can reach the ground water. Factors that determine whether enough oxygen is available for oxidation of ammonia and organic carbon include the depth to ground water and the texture and the moisture content of the soil. Walker, Bouma, Keeney, and Olcott (1973) described a septic system that was inundated by shallow ground water. Nitrification did not occur and the ammonia was sorbed on the soil beneath the septic field.

Nitrate concentrations in the effluent below a septic field can be 2 to 7 times the MCL (Wilhelm and others, 1994), and distinct plumes of nitrate-contaminated ground water may extend from the septic system. In some settings, denitrification may occur in the ground water below the septic field. However, because denitrification requires both organic carbon and anaerobic conditions in the ground water below the septic field, nearly complete oxidation of organic carbon in the aerobic zone below the septic field usually limits the amount of organic carbon available for denitrification. In the few septic-system investigations in which denitrification was found to have occurred, native organic material in the soil provided the carbon source (Wilhelm and others, 1994).

\section{Nitrogen Cycle in Corrals}

Manure and urine from cattle and horses contain much less water than domestic sewage and are deposited directly on the ground. Domestic sewage is almost entirely water and is disposed of in underground tanks. In addition, animal wastes may contain antibiotics, which inhibit microbial activity that otherwise might decompose the waste (Grigoropoulos and Loudermilk, 1979).

Cattle and horse manure and urine contain large amounts of nitrogen. Lauer and others (1976) found the average nitrogen content of eight samples of cattle manure to be 2.0 percent. Hantzsche and Finnemore (1992) reported that a single horse excretes twice as much nitrogen as a family of four. The large amounts of nitrogen in animal wastes can contribute large amounts of nitrogen to the soil. For example, Ball and Ryden (1984) reported that applications of nitrogen to the soil within urine-and-dung patches range from 30 to 100 grams per square meter ( 0.006 to 0.02 pounds per square foot). 
the loss of nitrogen to the atmosphere: Only about 40 percent of the nitrogen in liquid manure that is injected 1 to 2 centimeters ( 0.4 to 0.8 inch) below the land surface is lost whereas nearly all the nitrogen is lost in liquid manure applied to the land surface. In contrast, at about $10^{\circ} \mathrm{C}$, there is very little difference in nitrogen loss between surficial application and shallow injection of liquid manure.

Mielke and others (1974) investigated nitrate movement through soil in cattle feedlots in eastern Nebraska. Manure on the land surface inhibits water movement and vertical leaching of nitrogen-containing wastes because hydrophilic substances in the manure swell when it is wet. Soil compaction, caused by hoof action, also impedes water movement.

Because the ammonia in animal wastes is exposed to atmospheric effects such as wind and drying, the loss of ammonia through volatilization is undoubtedly much greater from animal wastes than from human wastes, which is disposed of in underground tanks and is thus isolated from atmospheric effects. Therefore, even though domestic animals produce more nitrogen than humans do, probably more animal nitrogen than human nitrogen is lost to the air.

\section{IDENTIFICATION OF CONTAMINANT SOURCES}

Judging on the basis of theory alone whether or not a given method would be useful in solving a particular field research problem is often impossible. Because the meaning of a single piece or type of data may be ambiguous, the combination of several different methods commonly produces the best results for identifying sources of contaminants. Two principal types of evidence are discussed in this report: (1) stable isotopes of contaminants and of water and (2) water-quality measurements and analyses of nitrogen contaminants and other chemicals associated with the contaminant sources.

\section{Use of stable isotopes}

Stable isotopes are nonradioactive forms of an element; isotopes of a given element have the same number of protons but a different number of neutrons. The nitrogen isotopes ${ }^{15} \mathrm{~N}$ and ${ }^{14} \mathrm{~N}$ constitute an isotope pair. The lighter isotope ${ }^{14} \mathrm{~N}$ is more abundant; in the atmosphere there is one atom of ${ }^{15} \mathrm{~N}$ per 273 atoms of ${ }^{14} \mathrm{~N}$ (Drever, 1988). Measurements of the ratio of the abundance of the heavier isotope to that of the lighter isotope in a substance can provide useful information because the slight differences in the mass of the isotopes cause slight differences in their behavior. Isotope values for nitrogen and other elements are presented in the delta notation:

$$
\delta^{15} \mathrm{~N}=\left\{\left[\left(15 \mathrm{~N} /{ }^{14} \mathrm{~N}\right)_{\text {sample }}+\left({ }^{15} \mathrm{~N} /{ }^{14} \mathrm{~N}\right) \text { air }\right]-1\right\} \times 1000
$$

Several steps in the nitrogen cycle result in fractionation. In other words, changes in the stable-isotope composition of a nitrogen-containing chemical occur as a result of chemical reactions. Isotopic effects, caused by slight differences in the mass of two isotopes, tend to cause the heavier isotope to remain in the starting material of a chemical reaction. Denitrification, for example, causes the nitrate of the starting material to become isotopically heavier. Volatilization of ammonia results in the lighter isotope preferentially being lost to the atmosphere, and the ammonia that remains behind becomes isotopically heavier.

These isotopic effects mean that, depending on its origin, the same compound may have different isotopic compositions. For stable isotopes to provide a useful tool in identifying sources of nitrogen contamination, the isotopic composition of the potential source materials must be distinguishable. The major potential sources of nitrogen contamination in the hydrosphere commonly have characteristic ${ }^{15} \mathrm{~N} /{ }^{14} \mathrm{~N}$ ratios. Typical $\delta^{15} \mathrm{~N}$ values for important sources of nitrogen contamination are presented in table 2 .

TABLE 2.-Nitrogen isotope ratios of common sources of nitrate in water (Heaton, 1986)

\begin{tabular}{lc}
\hline $\begin{array}{c}\text { Potential contaminant } \\
\text { source }\end{array}$ & $\begin{array}{c}\delta^{15} \mathrm{~N} \\
\text { (permil) }\end{array}$ \\
\hline Commercial fertilizer & -4 to +4 \\
Animal waste & Greater than +10 \\
Precipitation & -3 \\
Organic nitrogen in soil & +4 to +9 \\
\hline
\end{tabular}


Even when the stable-isotope composition of the source material is known, what reactions occur after its deposition and how they affect its isotopic composition also must be known if the source of nitrate in ground water is to be identified. Although volatilization of ammonia causes significant enrichment of ${ }^{15} \mathrm{~N}$ in the ammonia that remains, the actual amount of fractionation that will occur in a natural setting is variable (Wassenaar, 1995). When the conversion of ammonia to nitrate is rapid and goes to completion, no fractionation occurs (Exner and Spalding, 1994). Denitrification, if it occurs, also causes the nitrate that remains to become progressively enriched in ${ }^{15} \mathrm{~N}$. Chien and others (1977) presented data for the loss of nitrate from an agricultural soil; they found that the loss of 60 percent of the initial nitrate caused the $\delta^{15} \mathrm{~N}$ of the residual nitrate to increase almost 20 permil.

Because fractionation after deposition blurs the isotopic signatures of the source materials, the use of ${ }^{15} \mathrm{~N}$ data alone may not be sufficient to differentiate among sources. Predicting isotopic changes in nature is extremely difficult; Heaton (1986) concluded that the unpredictable magnitude of fractionation in natural settings restricts the use of nitrogen isotope data to semiquantitative interpretations.

Stable isotopes of oxygen, used together with nitrogen isotope data, may be useful in determining sources of nitrate in ground water. In nitrate produced by commercial processes, such as commercial fertilizer, the oxygen is derived from atmospheric oxygen, which is isotopically heavy $\left(\delta^{18} \mathrm{O}=+23.5\right.$ permil) (Amberger and Schmidt, 1987 ). In nitrate produced by nitrification in receiving waters, two of the three atoms of oxygen are from local water and the remaining oxygen atom is from the air (Wassenaar, 1995). Because oxygen in the local meteoric water is isotopically light, $\delta^{18} \mathrm{O}$ values for fertilizer nitrate should be distinct from nitrate from animal wastes.

Wassenaar (1995) stated that nitrate from human wastes disposed of in domestic septic systems cannot be distinguished isotopically from animal wastes. However, if the water associated with human wastes were isotopically different from that associated with animal wastes, $\delta^{18} \mathrm{O}$ values for nitrate might be useful in differentiating between nitrate sources. Such isotopic differences between waters associated with humans and animals might arise as water evaporates from a trough or if water for household use has a different source from that of water used in a corral. Local precipitation may be isotopically distinct from ground water used in households and could also be a source of oxygen during nitrification in corrals.
Nitrogen and oxygen isotopes, alone, have been used successfully to identify sources of nitrogen contamination. (For further discussion, see "Case Studies.")

\section{Use of Characteristic Chemical Components}

Although stable-isotope data can be used alone, this type of data is most effective when used in combination with other data. Certain chemicals are characteristic of domestic sewage and probably are not found in animal wastes. Thus, identification of these chemicals in contaminated ground water can provide positive evidence that domestic sewage is at least a partial source of contamination. Similarly, the identification of certain pharmaceutical compounds used for large animals could provide strong evidence that animal wastes are a source of contamination.

The following two sections identify characteristic chemical components of domestic sewage and animal wastes.

\section{Chemical Components of Domestic Sewage}

Thurman and others (1984) characterized the chemical composition of a plume resulting from the disposal of treated sewage effluent to a sand and gravel aquifer on Cape Cod, Mass. Components that they used to distinguish the contaminant plume from the native ground water included

- Dissolved solids (DS)

- Boron

- Dissolved organic carbon (DOC)

- Methylene blue active substances (MBAS)

- Volatile organic compounds (VOC)

Their attempt to use major cations and anions to distinguish the plume from native ground water was only partially successful in their research setting.

Robertson and others (1991) characterized the chemical composition of two contaminant plumes from on-site septic systems near Cambridge, Ontario, Canada. They were successful in using major cations and anions to differentiate the contaminant plumes from native ground water; concentrations of sodium, calcium, potassium, and chloride were elevated in the plumes compared with background levels. Of all the constituents they measured, sodium was the best indicator of contamination from the septic system because its concentrations in the plume were 10 to 20 times greater than the background level. 
DS concentration and its surrogate, specific conductance, are nonspecific indicators of contamination. Domestic water use increases the DS concentration through the addition of salts, detergents, and other household byproducts. Aerobic oxidation of domestic-waste effluent causes acidity, which can dissolve minerals in the subsurface and hence can increase the DS concentration of the water. Over a 20 -year period, this process could dissolve from 225 to 900 kilograms (about 500 to 2,000 pounds) of $\mathrm{CaCO}_{3}$ below a typical septic system (Wilhelm and others, 1994).

The concentration of calcium in ground water is commonly greater than the sodium concentration. Domestic water use can change the ratio of calcium to sodium. Sodium is added to water during food preparation, and cation-exchange resins in water softeners replace calcium in the water with sodium. Thus the ratio of calcium to sodium may be a good tracer of sewage in ground water. At the Cape Cod site, sodium and calcium were not useful in distinguishing the septic plume because of the high sodium concentrations in the native ground water.

The ratio of sodium to chloride concentrations in the water may be useful in identifying sources of nitrate. According to chemical analyses presented by Harrill (1973) for Lemmon Valley, Nev., in most cases where nitrate concentrations were elevated, the $\mathrm{Na}$-to- $\mathrm{Cl}$ ratio was less than 2:1. Nowlin (1982) investigated sources of nitrate contamination near Topaz Lake in Nevada and found that elevated concentrations of nitrate were associated with $\mathrm{Na}$-to- $\mathrm{Cl}$ ratios in the range 0.9 to 1.7 .

Because of its widespread use, boron may generally be a good tracer of sewage in ground water (Thurman and others, 1984). Boron has numerous industrial and household uses-as a cleaning agent; as a water softener in washing powders; and in insecticidal, antibacterial, and antifungal agents. Boron concentrations in effluent at the Cape Cod site were about $500 \mu \mathrm{g} / \mathrm{L}$ and were less than 30 $\mu \mathrm{g} / \mathrm{L}$ in the native ground water. The use of boron in identifying contaminant plumes in Nevada may be more limited because the widespread thermal and volcanic waters may contain high natural concentrations of boron (Hem, 1985, p. 129).

DOC in ground water includes natural organic matter as well as organic matter from sewage. Although untreated domestic wastewater originally contains total organic-carbon concentrations of about 80 to $290 \mathrm{mg} / \mathrm{L}$ (Tchobanoglous and Burton, 1991), aerobic oxidation of the waste reduces the DOC concentration to low levels. In sewage-treatment plants, aerobic oxidation of organic matter is so thorough that methanol must be added to the effluent so that removal of nitrogen from the wastewater by denitrifying bacteria can occur (Tchobanoglous and Burton, 1991). Depending on the DOC concentration of the native ground water, DOC contributed by domestic waste may or may not serve to identify contaminant plumes.

MBAS are anionic surfactants that commonly are added to fertilizers, to pesticides, and to some household consumer products (such as detergents, shampoo, and toothpaste). One major type of MBAS used in detergents is branched-chain alkylaryl sulfonates (ABS). ABS are resistant to biodegradation and their use in detergents was discontinued in 1965 (Plummer and others, 1993). Another type of MBAS, linear alkylaryl sulfonates (LAS), are biodegraded more easily but still persist in ground water. On Cape Cod, Thurman and others (1984) could identify the location of the sewage-contaminant plume by the presence of MBAS and could distinguish contaminants discharged before the mid-1960's by the presence of ABS. Because MBAS are used in fertilizers also, MBAS may not be suitable to differentiate between fertilizer and sewage sources of nitrogen.

It may be possible to identify in wastewater some chemicals derived from products that are consumed by humans but not by animals. Beverages containing caffeine (such as coffee, tea, and soft drinks) can be disposed of directly into septic systems, and some caffeine may pass unmetabolized through the digestive system. Caffeine was found to be a significant component of wastewater effluent that has undergone secondary treatment (Sievers and others, 1977). Other consumer chemicals, such as aspirin, ibuprofen, or nicotine (from tobacco products), also may be identifiable in domestic sewage.

Chlorofluorocarbons (CFC's) are stable but volatile organic compounds that were first produced for use as refrigerants in the late 1930's (Plummer and others, 1993). CFC's may be used in households as aerosol propellants, cleaning agents, and components of plastic containers. CFC's are now ubiquitous in the atmosphere and because of this can be expected to be found in all modern (post1940) ground water. Schultz and others (1976) and Busenberg and Plummer (1992) concluded that sewage is a major source of CFC's in surface and ground water. CFC concentrations in ground water that contains sewage-derived recharge are probably much greater than those in native ground water or ground water that contains recharge affected by animal wastes. 


\section{Chemical Components of Animal Wastes}

Although detailed chemical analyses of domestic sewage are available (see section "Chemical Components of Domestic Sewage"), no comparable chemical analyses of animal wastes have been identified. Detecting a chemical that is characteristic of animal wastes could provide strong evidence that animals are the source of nitrate contamination. Nitrate-contaminated water having nitrogen isotopes characteristic of animal or human wastes but lacking characteristic components of household wastes would not provide positive proof that animal wastes are the source of the nitrate contamination. However, if a chemical characteristic of animal wastes were coupled with these findings, then animal wastes would be strongly implicated as the source of the nitrate.

One group of chemicals that might be used as identifiers of animal wastes are veterinary pharmaceuticals used for control of internal parasites such as worms and flies. One pharmaceutical commonly used in Nevada is ivermectin. This belongs to a group of compounds that are products, or chemical derivatives thereof, of the bacteria Streptomyces avermitlis (Fraser and others, 1991). Most ivermectin is excreted in the feces, the remainder in the urine. Ivermectin in feces or soil decomposes at a slow but significant rate with a half life of 91 to 217 days under winter conditions (Fraser and others, 1991). One manufacturer of ivermectin sold in Nevada recommends doses every two months for the treatment of horses and cows (Farnam Companies, Inc., written commun., 1996).

Another pharmaceutical used in Nevada for the treatment of internal parasites is febantal, which belongs to the benzimidazole chemical family. The lethal effect of benzimidazoles is a slow process, and, hence, they are incorporated into some feed supplements to provide a repeated dose (Fraser and others, 1991).

Information was not found on the transport of the pharmaceuticals and their metabolites in the subsurface after they are excreted. For these chemicals to be useful as identifiers, they must migrate with the animal wastes and not be bound to soil particles. The potential exists for veterinary pharmaceuticals to be useful identifiers of animal wastes; however, the method has not been tried in a field setting.

\section{CASE STUDIES}

Several investigators have used stable isotopes of nitrogen and oxygen to differentiate fertilizer, animal wastes, and naturally occurring organic material as sources of nitrate contamination. Fewer investigators have attempted to differentiate between domestic sewage and animal wastes. The following eight case studies record the variable success in the use of stable isotopes to differentiate sources of contamination:

1. Kreitler and Jones (1975) used stable isotopes of nitrogen to differentiate natural sources from septic-system and feedlot sources in an area of Texas with very high concentrations of nitrate in the ground water. For nitrate that occurs naturally in the soil, the $\delta^{15} \mathrm{~N}$ range was 2 to 8 permil, whereas the range for animal-waste nitrates was 10 to 20 permil.

2. Wolterink and others (1979) reviewed the available literature and obtained new ground-water and soil data from 24 sites in 9 States. By using stable isotopes of nitrogen, they attempted to differentiate sources of nitrate as septic systems, feedlots, municipal wastewater (used for irrigation), or natural sources. They found that nitrate derived from septic-system effluent had a lower average $\delta^{15} \mathrm{~N}_{\mathrm{NO} 3}$ value $(+10.9$ permil) than the average $\delta^{15} \mathrm{~N}_{\mathrm{NO} 3}$ value of nitrate from feedlots and barnyards (+12.4 permil). On the basis of mean $\delta^{15} \mathrm{~N}$ values, they concluded that nitrate from septic systems and feedlots are indistinguishable. In their analysis of the data, Wolterink and others (1979) combined the results from ground-water and soil samples and used mean values for $\delta^{15} \mathrm{~N}$. However, the mean is not resistant to the effects of outliers; for chemical concentrations, the median is a better summary value. Included in their analysis were some soil samples from extremely shallow depths ( 0.1 meter) near septic systems. These samples had anomalously light $\delta^{15} \mathrm{~N}$ values $(-12.8$ to -20 permil), which are not typical of nitrogen derived from properly functioning septic systems.

3. Gormly and Spalding (1979) investigated three possible sources of nitrate contamination (feedlot waste, natural soil nitrogen, and fertilizers) in the Central Platte Region of Nebraska. They collected nitrogen data from soils below active and inactive or sporadically used feedlots and concluded that inactive feedlots contribute more nitrate to 
ground water than active feedlots. They suggested that manure packs on active feedlots form an effective barrier to vertical leaching. On the basis of $\delta^{15} \mathrm{~N}$ values of the potential source materials and the ground water, fertilizers applied to fields are the major source of contamination in their study area, although nitrate derived from feedlots may be the most important nitrate source at individual wells. Denitrification in the subsurface causes nitrogen fractionation but fertilizers still could be distinguished from animal wastes.

4. Flipse and others (1984) used stable isotopes of nitrogen to differentiate among several sources of nitrate contaminants in the ground water on Long Island, N.Y. For samples from 14 wells, $\delta^{15} \mathrm{~N}_{\mathrm{NO} 3}$ values ranged from 1.1 to 7.1 permil. They concluded that the nitrate was derived from fertilization of residential lawns and not from leaky sewer lines or animal wastes.

5. Komor and Anderson (1993) investigated sources of nitrate contamination of a shallow sand-plain aquifer in central Minnesota. They measured nitrogen concentrations and isotopic composition of nitrogen species from five land-use settings. (The land-use settings, average nitrate concentrations, and $\delta^{15} \mathrm{~N}_{\mathrm{NO} 3}$ values are summarized in table 3.) They concluded that nitrogen isotopes are useful as qualitative indicators of nitrate sources in their study area.
6. Aravena and others (1993) used the isotopes ${ }^{15} \mathrm{~N}$ and ${ }^{18} \mathrm{O}$ from nitrate to characterize a nitrate-contaminant plume emanating from a septic system. Their goal was to distinguish septic-system nitrate from nitrate derived from fertilizers, from solid cattle manure, and from natural soil nitrogen. $\delta^{15} \mathrm{~N}_{\mathrm{NO} 3}$ values from within the septic plume ranged from 8.1 to 13.9 permil and from outside the plume ranged from 3.4 to 6.2 permil; thus $\delta^{15} \mathrm{~N}_{\mathrm{NO} 3}$ values can be used to distinguish septic-system nitrate from other nitrate. Distinguishing the relative importance of contributions from fertilizers, solid cattle manure, and natural soil nitrogen by using $\delta^{15} \mathrm{~N}$ values was not successful. Because the oxygen incorporated into nitrate is derived in part from local water, Aravena and others (1993) tested whether $\delta^{18} \mathrm{O}_{\mathrm{NO} 3}$ could be used to differentiate the source of water used during nitrification and hence the source of the nitrate. In their research setting, the $\delta^{18} \mathrm{O}_{\mathrm{NO} 3}$ of the plume and nonplume ground water differed by about 1 permil. The values of $\delta^{18} \mathrm{O}_{\mathrm{NO} 3}$ from plume and nonplume water did not differ statistically and could not be used to differentiate between nitrate sources.

7. Gellenbeck (1994) used stable isotopes of water, nitrogen, sulfur, lithium, and boron to differentiate among different sources of nitrate contamination near Phoenix, Ariz. Four sources of nitrate were studied: dairies

TABLE 3.-Land use and nitrate characteristics of sand-plain aquifer in Minnesota (Komar and Anderson, 1993)

\begin{tabular}{lccc}
\hline \multirow{1}{*}{ Land use } & $\begin{array}{c}\text { Mean nitrate } \\
\text { concentration } \\
(\mathrm{mg} / \mathrm{L})\end{array}$ & \multicolumn{2}{c}{$\begin{array}{c}\delta^{15} \mathrm{~N}_{\text {NO3 }} \\
\text { (permil) }\end{array}$} \\
\cline { 4 - 5 } & & Range & Mean \\
\hline Natural (undeveloped) areas & 3.8 & $1.7-5.5$ & 3.1 \\
$\quad$ Cultivated fields: & 13.0 & $0.9-22.6$ & 7.4 \\
$\quad \begin{array}{l}\text { Irrigated } \\
\quad \text { Nonirrigated }\end{array}$ & 15.5 & $-2.2-6.1$ & 3.4 \\
Residential areas with septic systems & 8.3 & $1.8-12$ & 6 \\
Livestock feedlots & 12.7 & $8.9-45$ & 21.3 \\
\hline
\end{tabular}


and feedlots, sewage-treatment plants, fertilizers used on cotton and citrus crops, and natural sources. Nitrate from dairies and feedlots was identified by $\delta^{15} \mathrm{~N}$ values greater than +9.0 permil. Nitrate from sewagetreatment plants was identified best by the stable isotopes ${ }^{15} \mathrm{~N},{ }^{34} \mathrm{~S},{ }^{7} \mathrm{Li}$, and ${ }^{11} \mathrm{~B}$.

8. Wassenaar (1995) used stable isotopes of nitrogen and oxygen to evaluate the origin of nitrate-contaminated water in southwestern British Columbia, Canada. The principal nitrogen sources are poultry manure (used as fertilizer) and inorganic fertilizers. The $\delta^{15} \mathrm{~N}_{\mathrm{NO} 3}$ and $\delta^{18} \mathrm{O}_{\mathrm{NO} 3}$ data show that poultry manure is the principal source of nitrate in the aquifer and that no significant denitrification is taking place. The $\delta^{18} \mathrm{O}_{\mathrm{NO} 3}$ data suggest that nitrification occurs principally during the summer, when isotopically heavy summer precipitation is the source of oxygen used during nitrification.

Although the association of CFC's and caffeine with sewage has been reported in the literature (see section "Chemical Components of Domestic Sewage"), no investigations that used these chemicals to differentiate human sewage from other sources of nitrogen contamination were identified. The following four studies describe investigations that characterize the composition of sewage:

9. Schultz and others (1976) described their attempt to use CFC's to trace ground-water recharge from sewage effluent. Treated sewage effluent from Tucson, Ariz., was used for irrigation or discharged to a normally dry riverbed. Sewage contamination of ground water near the river was mapped by the use of nitrate and chloride. However, elevated nitrate concentrations did not correlate well with $\mathrm{CFC}$ values.

10. Busenberg and Plummer (1992) described methods to collect and preserve samples for CFC analysis and discussed the use of CFC's as hydrologic tracers. They sampled CFC's at $\mathbf{5 7}$ sites in rivers and streams upstream and downstream from major sewage-treatment plants in central Oklahoma. High concentrations of CFC's were detected consistently at the sites downstream from sewage sources, and background concentrations of CFC's were found upstream from the sewage sources. Some sites near sewage-disposal ponds and near treated-sewage returns into streams in their study area had anomalously high CFC concentrations in the ground water. Busenberg and Plummer (1992) concluded that sewage-disposal ponds and treated-sewage returns are major sources of the CFC's found in natural waters.

11. Albaiges and others (1986) investigated the organic composition of leachate from a sanitary landfill in Barcelona, Spain. They identified several compounds, including nicotine and caffeine, that had been leached from the landfill by percolating waters.

12. Buszka and others (1994) sampled water and streambed sediment for organic compounds at sites upstream and downstream from a municipal wastewater-treatment plant near Dallas, Tex. They detected caffeine, several VOC's, and MBAS in water as far downstream as 8.4 miles from the treatment plant.

\section{SUMMARY AND CONCLUSIONS}

Elevated concentrations of nitrate have been detected in ground water used as a source of drinking water in Lemmon and Golden Valleys in Washoe County, Nev. In this area, local ground-water withdrawals for drinking water greatly exceed natural recharge, and recharge from septic-system effluent is becoming an increasingly large part of the recharge to the aquifer. Because both treatment and prevention of contamination are very expensive, methods are needed to identify the principal sources of the nitrogen in the ground-water system.

In Lemmon Valley, septic-system effluent and animal wastes from corrals are probably the major sources of the nitrogen in the ground-water system; fertilizers and natural sources of nitrogen are probably of secondary importance. The literature was reviewed to identify methods for differentiating between possible sources of nitrogen contamination.

A combination of chemical analyses probably best differentiates between sources of nitrogen contamination, because the meaning of a single piece or type of data can be ambiguous. Certain chemicals are characteristic of septic-system effluent, and the finding of a characteristic suite of these chemicals could provide strong evidence that septic-system effluent is the local source of nitrogen 
contamination. Pharmaceuticals used in the treatment of large animals have the potential to identify corrals as a local source of nitrogen contamination. Stable isotopes of nitrogen can be used effectively to differentiate animal waste from fertilizers or natural sources as sources of nitrogen contamination.

The following suite of chemical analyses may provide an effective means of identifying the sources of nitrogen contamination in Lemmon Valley:

- Major ions and boron

- Nitrogen $\left(\mathrm{NO}_{2}, \mathrm{NO}_{2}+\mathrm{NO}_{3}, \mathrm{NH}_{3}\right.$, organic nitrogen)

- Dissolved organic carbon

- Methylene blue active substances

- Chlorofluorocarbons

- Semivolatile organic compounds (includes caffeine, nicotine, and pharmaceuticals)

- Stable isotopes $\left(\delta^{15} \mathrm{~N}_{\mathrm{NO} 3}, \delta^{18} \mathrm{O}_{\mathrm{NO} 3}, \delta^{15} \mathrm{~N}_{\mathrm{NH} 3}\right.$, $\left.\delta^{2} \mathrm{H}_{\mathrm{H} 2 \mathrm{O}}, \delta^{18} \mathrm{O}_{\mathrm{H} 2 \mathrm{O}}\right)$

\section{REFERENCES CITED}

Albaiges, J., Casado, F., and Ventura, F., 1986, Organic indicators of groundwater pollution by a sanitary landfill: Water Research, v. 20, no. 9, p. 1153-1159.

Alhajjar, B.J., Harkin, J.M., and Chesters, Gordon, 1989, Detergent formula and characteristics of wastewater in septic tanks: Journal of the Water Pollution Control Federation, v. 61, p. 605-613.

Amberger, Annette, and Schmidt, H.L., 1987, Natürliche Isotopengehalte von Nitrat als Indikatoren für dessen Herkunft [Natural isotope abundance of nitrate as an indicator of its origin]: Geochemica et Cosmochimica Acta, v. 51, p. 2699-2705.

Aravena, R., and Evans, M.L., and Cherry, J.A., 1993, Stable isotopes of oxygen and nitrogen in source identification of nitrate from septic systems: Ground Water, v. 31, no. 2, p. 180-186.

Balkwill, D.L., 1989, Numbers, diversity, and morphological characteristics of aerobic, chemoheterotrophic bacteria in deep subsurface sediments from a site in South Carolina: Geomicrobiological Journal, v. 7, p. 33-52.

Ball, P.R., and Ryden, J.C., 1984, Nitrogen relationships in intensively managed temperate grassland: Plant and Soil, v. 76, p. 23-33.

Bouwer, Herman, 1978, Groundwater hydrology: New York, McGraw-Hill, 480 p.
Brown, K.W., Donnelly, K.C., Thomas, J.C., and Slowey, J.F., 1984, The movement of nitrogen species through three soils below septic fields: Journal of Environmental Quality, v. 13, p. 460-465.

Busenberg, Eurybiades, and Plummer, L.N., 1992, Use of chlorofluorocarbons $\left(\mathrm{CCl}_{3} \mathrm{~F}\right.$ and $\left.\mathrm{CCl}_{2} \mathrm{~F}_{2}\right)$ as hydrologic tracers and age-dating tools: the alluvium and terrace system of Central Oklahoma: Water Resources Research, v. 28, no. 9, p. 2257-2283.

Buszka, P.M., Barber, L.B., II, Schroeder, M.P., and Becker, L.D., 1994, Organic compounds downstream from a treated waste-water discharge near Dallas, Texas, March 1987: U.S. Geological Survey Water-Resources Investigations Report 93-4194, 19 p.

Canter, L.W., and Knox, R.C., 1986, Septic tank system effects on ground water quality: Chelsea, Mich., Lewis Publishers, $336 \mathrm{p}$.

Cardinalli, J.L., Roach, L.M., Rush, F.E., and Vasey, B.J., comps., 1968, State of Nevada hydrographic areas: Nevada Division of Water Resources map, scale 1:500,000.

Chien, S.H., Shearer, Georgia, and Kohl, D.H., 1977, The nitrogen isotope effect associated with nitrate and nitrite loss from water-logged soils: Soil Science Society of America Journal, v. 41, p. 63-69.

Drever, J.I., 1988, The geochemistry of natural waters: Englewood Cliffs, N.J., Prentice-Hall, 437 p.

Exner, M.E., and Spalding, R.F., 1994, N-15 identification of nonpoint sources of nitrate contamination beneath cropland in the Nebraska Panhandle-Two case studies: Applied Geochemistry, v. 9, p. 73-81.

Flipse, W.J., Katz, B.G., Lindner, J.B., and Markel, Richard, 1984 , Sources of nitrate in ground water in a sewered housing development, central Long Island, New York: Ground Water, v. 22, no. 4, p. 418-426.

Fraser, C.F., Bergeron, J.A., Mays, Asa, and Aiello, S.E., eds., 1991, The Merck veterinary manual: Rahway, N.J., Merck and Co., Inc., 1382 p.

Gellenbeck, D.J., 1994, Isotopic compositions and sources of nitrate in ground water from western Salt River Valley, Arizona: U.S. Geological Survey, Water-Resources Investigations Report 94-4063, 53 p.

Ghiorse, W.C., and Wilson, J.T., 1988, Microbial ecology of the terrestrial subsurface: Advances in Applied Microbiology, v. 33, p. 107-172.

Gormly, J.R., and Spalding, R.F., 1979, Sources and concentrations of nitrate-nitrogen in ground water of the Central Platte Region, Nebraska: Ground Water, v. 17, no. 3, p. 291-301.

Grigoropoulos, S.G., and Loudermilk, A.H., Jr., 1979, Staged lagoon treatment of feedlot waste: Journal of the Water Pollution Control Federation, v. 51, p. 163-175. 
Hantzsche, N.N., and Finnemore, E.J., 1992, Predicting ground-water nitrate-nitrogen impacts: Ground Water, v. 30 , no. 4 , p. $490-499$.

Harrill, J.R., 1973, Evaluation of the water resources of Lemmon Valley, Washoe County, Nevada, with emphasis on effects of ground-water development to 1971: Nevada State Engineer Water-Resources Bulletin 42, $130 \mathrm{p}$.

Heathwaite, A.L., 1993, Nitrogen cycling in surface waters and lakes, in Burt, T.P., Heathwaite, A.L., and Trudgill, S.T., eds., Nitrate-Processes, patterns, and management: Chichester, England, John Wiley, p. 99-140.

Heaton, T.H.E., 1986, Isotopic studies of nitrogen pollution in the hydrosphere and atmosphere-A review: Chemical Geology, v. 59, p. 87-102.

Hem, J.D., 1985, Study and interpretation of the chemical characteristics of natural water (3d ed.): U.S. Geological Survey Water-Supply Paper 2254, 283 p.

Howard-Williams, C., and Downes, M.T., 1993, Nitrogen cycling in wetlands, in Burt, T.P., Heathwaite, A.L., and Trudgill, S.T., eds., Nitrate-Processes, patterns, and management: Chichester, England, John Wiley, p. 141-167.

Komor, S.C., and Anderson, H.W., Jr., 1993, Nitrogen isotopes as indicators of nitrate sources in Minnesota sand-plain aquifers: Ground Water, v. 31, no. 2, p. 260-270.

Kreitler, C.W., and Jones, D.C., 1975, Natural soil nitrateThe cause of nitrate contamination of ground water in Runnels County, Texas: Ground Water, v. 13, no. 1, p. 53-61.

La Lande Cremer, L.C.N. de, 1986, Dutch experience with slurry injection, in Dam Kofoed, A., Williams, J.H., and L'Hermite, P., eds., Efficient land use of slurry and manure: London, Elsevier, p. 99-105.

Lauer, D.A., Bouldin, D.R., and Klausner, S.D., 1976, Ammonia volatilization from dairy manure spread on the soil surface: Journal of Environmental Quality, v. 5, no. 2, p. 134-141.

Lehninger, A.L., 1970, Biochemistry: New York, Worth Publishers, $833 \mathrm{p}$.

Mielke, L.N., Swanson, N.D., and McCalla, T.M., 1974, Soil profile conditions of cattle feedlots: Journal of Environmental Quality, v. 3, no. 1, p. 14-17.

National Academy of Sciences, 1978, Nitrates-An environmental assessment: Washington, D.C., National Academy of Sciences, $723 \mathrm{p}$.

Nevada Bureau of Health Protection Services, 1992, Public water system-Quality: Nevada Administrative Code, chap. 445, p. 49-52.

Nowlin, J.O., 1982, Ground-water levels and water quality in an area near Topaz Lake, Douglas County, Nevada: U.S. Geological Survey Open-File Report 80-2046, $76 \mathrm{p}$.
Okada, K., Ogasa, K., Yamamoto, K., and Ishibashi, N., 1978, A mechanism for biological denitrification in aerated lagoon system, in Ouano, E.A.R., Lohani, B.N., and Thanh, N.C., eds., International Conference on Water Pollution Control in Developing Countries, Bangkok, Thailand, 1978, Proceedings: Bangkok, Thailand, Asian Institute of Technology, p. 675-680. [Available also from Pergamon Press, New York.]

Paerl, H.W., 1993, Interaction of nitrogen and carbon cycles in the marine environment, in Ford, T.E, Aquatic microbiology, Cambridge, Mass., Blackwell Scientific, p. 343-381.

Patt, R.O., and Hess, J.W., 1976, Characterization of nitrogen sources contaminating shallow ground water in an arid basin, Las Vegas area, Nevada: Las Vegas, University of Nevada, Desert Research Institute, Hydrology and Water Resources Publication 26, $44 \mathrm{p}$.

Plummer, L.N., Michel, R.L., Thurman, E.M., and Glynn, P.D., 1993, Environmental traces for age dating young ground water, in Alley, W.M., ed., Regional groundwater quality: New York, Van Nostrand Reinhold, p. 255-294.

Reneau, R.B., Jr., Hagedorn, C., and Degen, M.J., 1989, Fate and transport of biological and inorganic contaminants from on-site disposal of domestic wastewaters: Journal of Environmental Quality, v. 18, p. 135-144.

Robertson, W.D., Cherry, J.A., and Sudicky, E.A., 1991, Ground-water contamination from two small septic systems on sand aquifers: Ground Water, v. 29, no. 1,p. 82-92.

Rush, F.E., 1968, Index of hydrographic areas in Nevada: Nevada Department of Conservation and Natural Resources, Water Resources Information Series Report $6,38 \mathrm{p}$

Rush, F.E., and Glancy, P.A., 1967, Water-resources appraisal of the Warm Springs-Lemmon Valley area, Washoe County, Nevada: Nevada Department of Conservation and Natural Resources, Water Resources Reconnaissance Series Report 43, $70 \mathrm{p}$.

Salisbury, F.B., and Ross, Cleon, 1969, Plant physiology: Belmont, Calif., Wadsworth Publishing, 747 p.

Schultz, T.R., Randall, J.H., Wilson, L.G., and Davis, S.N., 1976, Tracing sewage effluent recharge-Tucson, Arizona: Ground Water, v. 14, no. 6, p. 463-471.

Sievers, R.E., Barkley, R.M., Eiceman, G.A., Shapiro, R.H., and Walton, H.F., 1977, Environmental trace analysis of organics in waste water by glass capillary column chromatography and ancillary techniques: Journal of Chromatography, v. 142, p. 745-754.

Stewart, B.A., 1970, Volatilization and nitrification of nitrogen from urine under simulated cattle feedlot conditions: Environmental Science and Technology, v. 4, p. 579-582. 
Stewart, B.A., Viets, F.J., Jr., Hutchinson, G.L., Kemper, W.D., 1967, Nitrate and other water pollutants under fields and feedlots: Environmental Science and Technology, v. 1, p. 736-739.

Tchobanoglous, George, and Burton, F.L., 1991, Wastewater engineering-Treatment, disposal, and reuse, New York, McGraw-Hill, 1334 p.

Thurman, E.M., Barber, L.B., II, Ceazan, M.L., Smith, R.L., Brooks, M.G., Schroeder, M.P., Keck, R.J., Driscoll, A.J., LeBlanc, D.R., and Nichols, W.J., Jr., 1984, Sewage contaminants in ground water, in LeBlanc, D.R., ed., 1984, Movement and fate of solutes in a plume of sewage-contaminated ground water, Cape Cod, Massachusetts: U.S. Geological Survey Open-File Report 84 475, p. 47-64.

U.S. Environmental Protection Agency, 1980, Design manual-On-site wastewater treatment and disposal systems: U.S. Environmental Protection Agency Report EPA-6625/1-77-008, 480 p.

----1986, National interim primary drinking-water regulations-Subpt. B, Maximum contaminant levels: U.S. Code of Federal Regulations, Title 40, pt. 141 [July 1, 1986, revision], p. 524-528, 567-568.

Van Denburgh, A.S., 1981, Water resources of Cold Spring Valley, a growing urban area northwest of Reno, Nevada: U.S. Geological Survey Open-File Report 80$1287,79 \mathrm{p}$.

Van Denburgh, A.S., Goerlitz, D.F., and Godsy, E.M., 1993, Depletion of nitrogen-bearing explosives wastes in a shallow ground-water plume near Hawthorne, Nevada [abs.], in Morganwalp, D.W., and Aronson, D.A., comps., U.S. Geological Survey Toxic Substances Hydrology Program-Abstracts of the Technical Meeting, Colorado Springs, Colo., September 20-24, 1993: U.S. Geological Survey Open-File Report 93-454, p. 172.

Van Hoozer, R.G., 1994, Simulating the effects of artificial recharge in Lemmon Valley, Washoe County, Nevada: University of Nevada M.S. thesis, 137 p.

Van Vuren, J.P.J., 1949, Soil fertility and sewage-An account of pioneer work in South Africa in the disposal of town wastes: New York, Dover, 236 p.

Vinten, A.J.A., and Smith, K.A., 1993, Nitrogen cycling in agricultural soils, in Burt, T.P., Heathwaite, A.L., and Trudgill, S.T., eds., Nitrate-Processes, patterns, and management: Chichester, England, John Wiley, p. 39-74.
Walker, W.G., Bouma, J., Keeney, D.R., and Magdoff, F.R., 1973, Nitrogen transformations during subsurface disposal of septic tank effluent in sands, Pt. 1, Soil transformations: Journal of Environmental Quality, v. 2, no. 4, p. 475-480.

Walker, W.G., Bouma, J., Keeney, D.R., and Olcott, P.G., 1973, Nitrogen transformations during subsurface disposal of septic tank effluent in sands, Pt. 2, Ground water quality: Journal of Environmental Quality, v. 2, no. 4 p. 521-525.

Washoe County Department of Comprehensive Planning, 1985, U.S. census neighborhood statistics programLemmon Valley: Washoe County Department of Comprehensive Planning report, $11 \mathrm{p}$.

Wassenaar, L.I., 1995, Evaluation of the origin and fate of nitrate in the Abbotsford Aquifer using the isotopes of ${ }^{15} \mathrm{~N}_{\text {and }}{ }^{18} \mathrm{O}$ in $\mathrm{NO}_{3}^{-}$: Applied Geochemistry, v. 10, p. 391-405.

Wells, E.R., and Krothe, N.C., 1989, Seasonal fluctuation in $\delta^{15} \mathrm{~N}$ of groundwater nitrate in a mantled karst aquifer due to macropore transport of fertilizer-derived nitrate: Journal of Hydrology, v. 112, p. 191-201.

Widmer, M.C., and McKay, W.A., 1994, Ground water contamination from septic tank effluent in a closed basin, Washoe County, Nevada: Washoe County Department of Public Works Utility Division, $64 \mathrm{p}$.

Wild, H.E., Jr., Sawyer, C.N., and McMahon, T.C., 1971, Factors affecting nitrification kinetics: Journal of the Water Pollution Control Federation, v. 43, no. 9, p. 1845-1854.

Wilhelm, S.R., Schiff, S.L., and Cherry, J.A., 1994, Biogeochemical evolution of domestic waste water in septic systems, Pt. 1, Conceptual model: Ground Water, v. 32 , no. 6, p. 905-916.

Winneberger, J.H.T., 1984, The septic tank, Vol. 2 of Septictank systems-A consultant's toolkit: Boston, Butterworth Publishers, $123 \mathrm{p}$.

Wolterink, T.J., Williamson, H.J., Jones, D.C., Grimshaw, T.W., and Holland, W.F., 1979, Identifying sources of subsurface nitrate pollution with stable nitrogen isotopes: U.S. Environmental Protection Agency Report EPA-600/4-79-050, $151 \mathrm{p}$. 